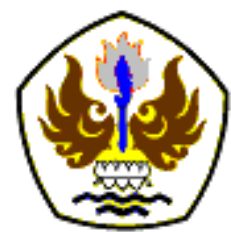

INFOMATEK

Volume 23 Nomor 2 Desember 2021

\title{
APLIKASI AUGMENTED REALITY SEBAGAI MEDIA PEMBELAJARAN PENGENALAN BAHASA INGGRIS BERBASIS ANDROID UNTUK SISWA SEKOLAH DASAR (Studi Kasus SDN 2 Kutanagara)
}

\author{
Sobarudin*, Maxsi Ary \\ Program Studi Sistem Informasi, Fakultas Teknologi Informasi \\ Universitas Adhirajasa Reswara Sanjaya
}

\begin{abstract}
Abstrak: Penggunaaan metode pembelajaran yang kurang menyenangkan atau monoton pada pembelajaran usia enam sampai tujuh tahun membuat siswa menjadi tidak fokus dan kurang perhatian ketika pembelajaran sedang berlangsung. Sedangkan penggunaan media pembelajaran sangat penting dan bermanfaat untuk membantu para siswa dalam meningkatkan minat belajar, pemahaman materi serta ketertarikan siswa terhadap materi pembelajaran terutama pembelajaran Bahasa Inggris, dimana Bahasa inggris sulit dipahami. Penelitian memanfaatkan augmented reality sebagai media pembelajaran. Sebagai implikasi dari pembuatan aplikasi diantaranya untuk menarik fokus, perhatian siswa dan lebih tertarik terhadap minat belajar. Serta memudahkan para guru atau orang tua, sehingga lebih mudah menjelaskan proses pembelajaran bahasa Inggris kepada siswa. Selain itu mampu menciptakan suasana belajar yang lebih menyenangkan. Pengembangan software menggunakan sebuah metode yaitu SDLC (System Development Life Cycle) dengan Waterfall Model. Hasil Penelitian ini adalah sebuah aplikasi augmented reality sebagai media pembelajaran yang menyenangkan dan dapat meningkatkan pemahaman materi, ketertarikan siswa terhadap materi yang sampaikan.
\end{abstract}

Kata kunci: Augmented reality, Media pembelajaran, Pengenalan bahasa Inggris

\section{PENDAHULUAN}

Perkembangan teknologi sekarang sudah memasuki era 4.0 sudah berkembangan dengan sangat pesat, salah satunya yaitu pada bidang pendidikan yang terkena dampak cukup besar dengan dengan adanya perkembangan teknologi ini. Pendidikan yaitu merupakan sebuah proses komunikasi dan informasi dari pendidik yang diberikan kepada

\footnotetext{
*) sobarudin1604@gmail.com

Pertama diterima: 12 Oktober 2021

Direvisi: 19 Oktober 2021

Disetujui untuk publikasi: 26 November 2021

DOI: 10.23969/infomatek.v23i2.4581
}

peserta didik yaitu berisi sebuah informasi pendidikan, yang mempunyai unsur-unsur pendidik sebagai sumber dari informasi, media sendiri yaitu sebagai sarana untuk penyajian ide, gagasan dan materi pendidikan (Husaini, 2014 [1], Yusril, 2019 [2]).

Pendidikan di Indonesia ada beberapa tingkatan yaitu dimulai dari SD, SMP dan SMA. Sekolah Dasar atau SD dianggap sebagai dasar dari pendidikan. Di sekolah Dasar para siswa mendapatkan pendidikan serta pembelajaran. Pendidikan SD atau 
sekolah dasar dibuat untuk memberikan sebuah dasar dari pengetahuan, sikap dan keterampilan untuk siswa. Berhubungan dengan tujuan dari operasional pendidikan sekolah dasar, yang ada di dalam Kurikulum Pendidikan Dasar yaitu memberikan bekal kemampuan dasar seperi dapat membaca, dapat menulis dan juga siswa dapat berhitung, dasar pengetahuan serta dasar keterampilan untuk siswa (Rachman, 2015 [3]).

Penggunaaan metode pembelajaran yang kurang menyenagkan atau monoton membuat siswa menjadi tidak fokus dan kurang perhatian pada saat pembelajaran berlangsung. Dengan digunakannya media pembelajaran menjadi sangat bermanfaat untuk membuat para siswa lebih tertarik kepada materi, serta memberikan pemahaman yang mudah terhapa materi pembelajaran Bahasa Inggris, dimana Bahasa Inggris sulit dipahami. Pembelajaran yang sulit membuat anak jadi kurang tertarik.

Bahasa Inggris merupakan bahasa internasional, maka dari itu Bahasa Inggris penting diberikan untuk anak sekolah dasar. Bahasa Inggris harus diberikan atau diperkenalkan kepada anak sedini mungkin tujuannya untuk membantu agar anak terbiasa dengan Bahasa Inggris. Dengan Berlatih mengucapkan sebuah kalimat atau sebuah kata dapat membantu anak terbiasa dengan Bahasa Inggris. Dengan metode yang menyenangkan dalam pembelajar membuat anak merasa nyaman dan senang pada saat pembelajaran berlangsung. Menyanyi dan mendengarkan sebuah lagu bersama-sama, serta membaca sebuah cerita bergambar adalah contoh beberapa metode untuk mengajarkan Bahasa Inggris. Akan tetapi harus berinovasi juga dengan metode yang baru untuk pembelajaran bahasa Inggris (Kalena, 2020 [4]). Interakitf dari sebuah media pembelajaran dengan adanya sebuah fasilitas seperti sebuah fitur 3D sangat membantu saat pembelajaran Bahasa Inggris berlangsung, media pembelajaran yang dimaksud yaitu media pembelajaran menggunakan augmented reality.

Augmented Reality (AR) merupakan teknologi yang menyatukan benda maya dua dan tiga dimensi dengan dunia nyata atau (Real) lalu menampilkan benda maya tersebut secara langsung. Teknologi Augmented Reality banyak digunakan oleh bidang kesehatan, bidang milter seperti pengenalan senjata, dalam bidang industri manufaktur ataupun dunia pendidikan. Teknologi augmented reality (AR) dapat memasukan sebuah informasi kedalam dunia maya lalu menampilkannya ke dalam dunia nyata dengan bantuan perlengkapan seperti komputer, HP Android (Mubaraq \& Kurniawan, 2018 [5]). Apabila teknologi ini dipakai dalam bidang pendidikan pada pembelajaran Bahasa Inggris yaitu dengan menampilkan objek 3D untuk mendukung pembelajaran pengenalan dan 
latihan soal Bahasa Inggris seperti huruf, angka, warna, dan buah-buahan yang menyerupai aslinya beserta audio sehingga menarik fokus, perhatian siswa dan lebih tertarik terhadap minat belajar. Berdasarkan Latar Belakang diatas, maka penulis mengambil judul: "Aplikasi Augmented Reality Sebagai Media Pembelajaran Pengenalan Bahasa Inggris Berbasis Android Untuk Siswa Sekolah Dasar (Studi Kasus SDN 2 Kutanagara)".

\section{METODOLOGI}

Metode yang dilakukan oleh penulis pada penelitian ini yaitu metode pengumpulan data dan metode pengembangan sistem. Untuk mengumpulkan data penulis menggunakan beberapa teknik, pengumpulan data yang digunakan yaitu observasi dan studi pustaka.

\subsection{Observasi (pengamatan)}

Metode observasi digunakan untuk mengumpulkan data tentang situasi dan kondisi kegiatan pembelajaran sehari-hari guru terhadap murid di SDN 2 Kutanaga dan orang tua kepada anak khusunya pembelajaran Bahasa Inggris.

\subsection{Studi Pustaka}

Penulis mencari literatur bacaan serta sumber referensi dari jurnal, buku dan informasi lainnya melalui internet yang mendukung dan berkaitan dengan topik penulisian skripsi untuk melengkpai data yang dibutuhkan.

\subsection{Pengembangan Software}

Pengembangan sotware menggunakan metode SDLC (System Development Life Cycle) dengan model Linear sequential model atau yang biasa disebut Waterfall Model. Penampilan gambar seperti pada Gambar 1.

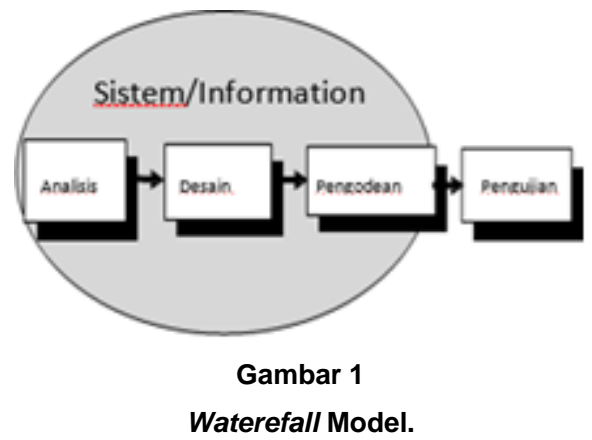

Pada perancangan Unified Modelling Language (UML) dibagi menjadi beberapa perancangan antara lain: use case diagram, activity diagram, class diagram, seperti pada Gambar2.

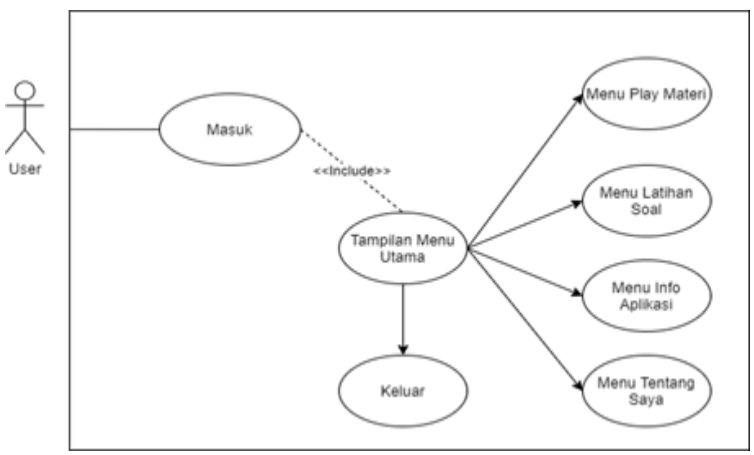

Gambar 2

Use Case Diagram. 


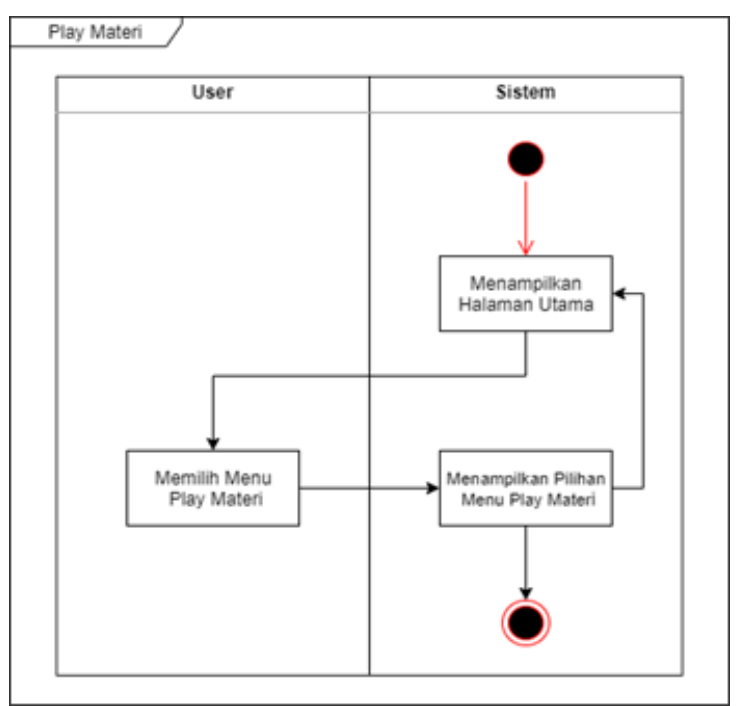

Gambar 3

Activity Diagram Menu Play Materi.

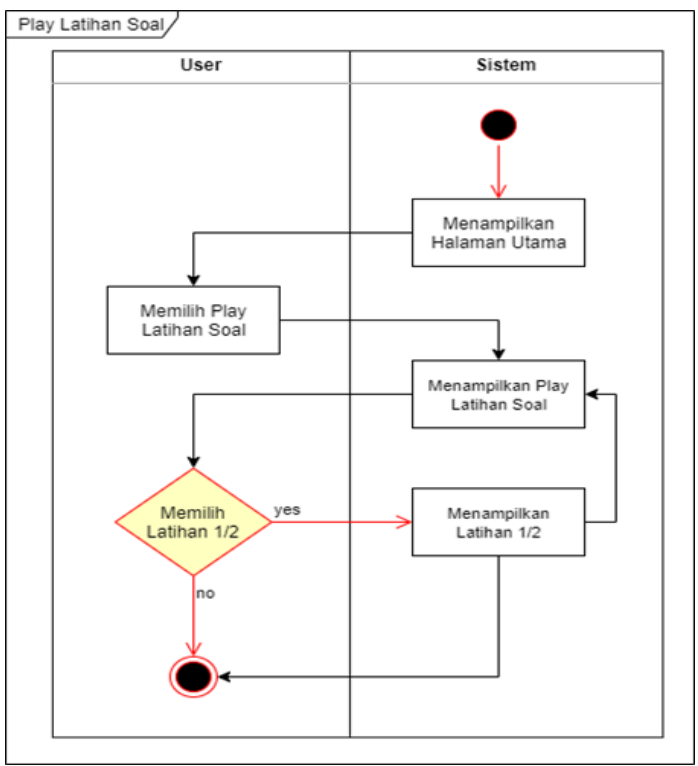

Gambar 4

Activity Diagram Menu Play Latihan.

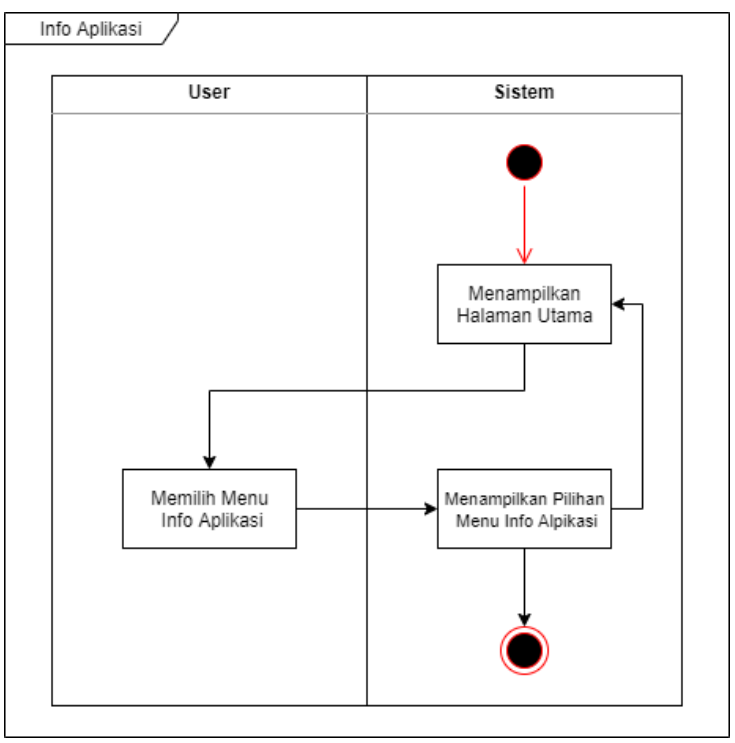

Gambar 5

Activity Diagram Menu Info Aplikasi.

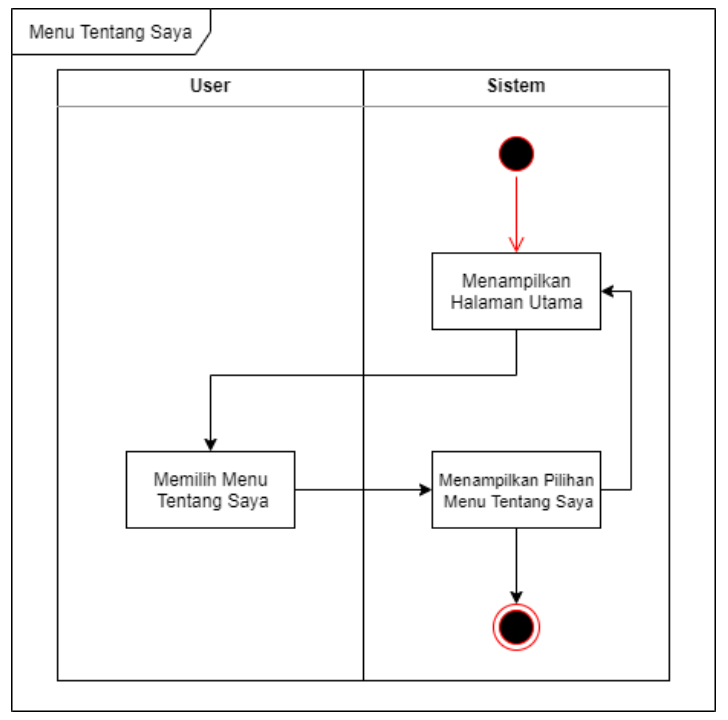

Gambar 6

Activity Diagram Menu Tentang Saya. 


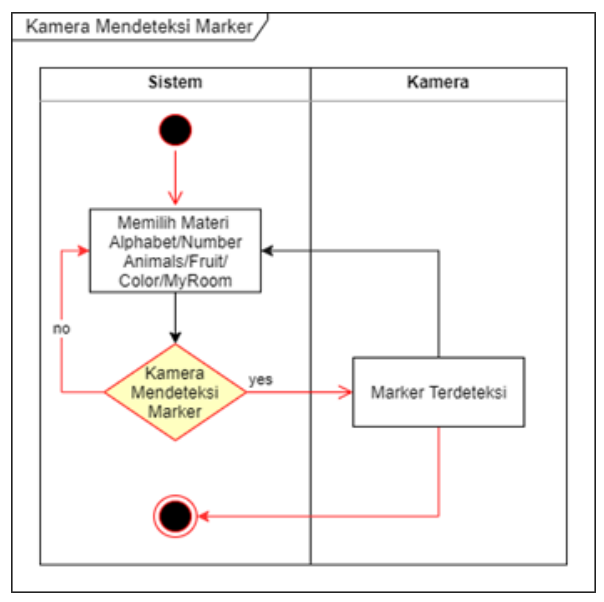

Gambar 7

Activity Diagram Kamera Mendetksi Marker.

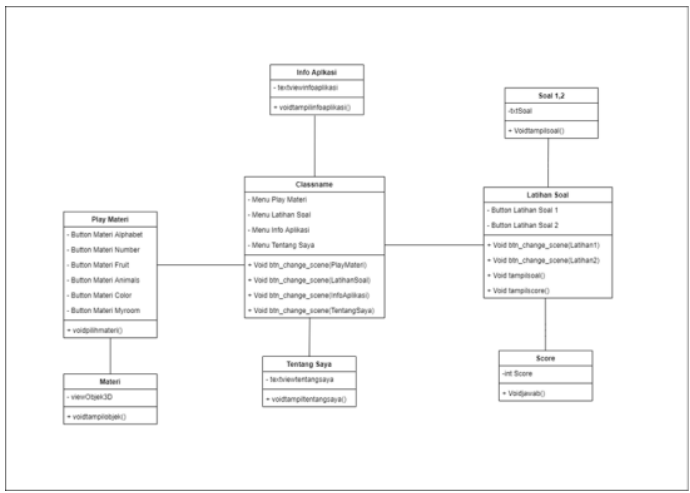

Gambar 8

Class Diagram.

\section{ANALISIS DAN PEMBAHASAN}

Hasil dari aplikasi merupakan screenshot dari aplikasi yang telah dibuat, antarmuka dari aplikasi ini adalah tampilan yang digunakan oleh pengguna atau user dalam menjalankan aplikasi augmented reality sebagai media pembelajaran pengenalan Bahasa Inggris. Beberapa tampilan halaman antarmuka aplikasi yang telah dibuat (Gambar 9 hingga 23).

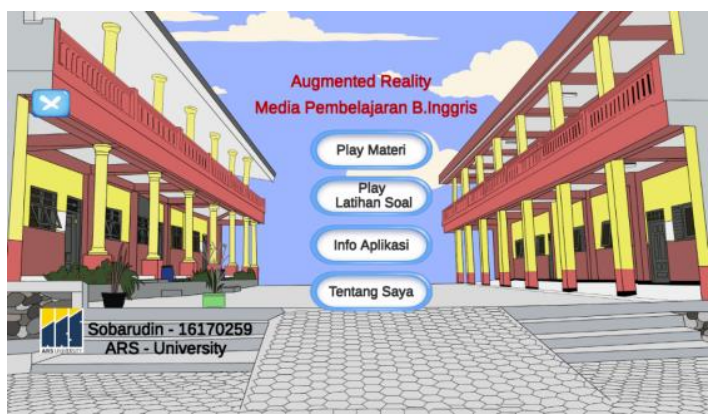

Gambar 9

Tampilan Menu Utama.

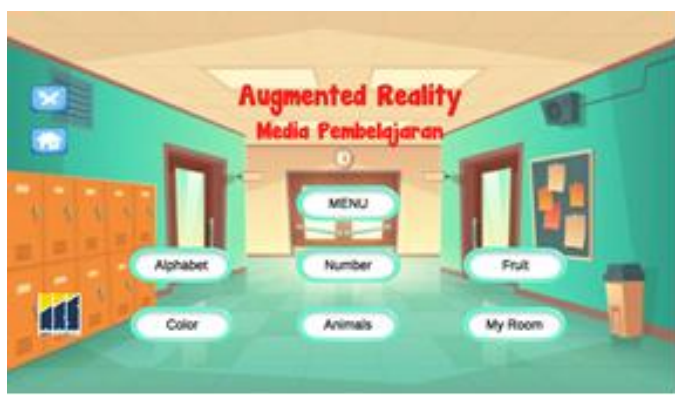

Gambar 10

Tampilan Menu Play Materi.

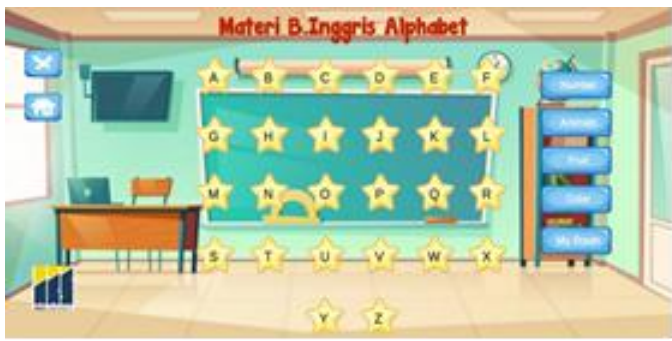

Gambar 11

Tampilan Materi Alphabet.

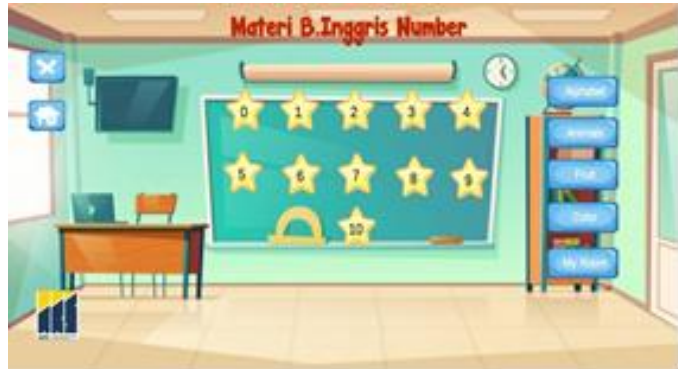

Gambar 12

Tampilan Materi Number. 


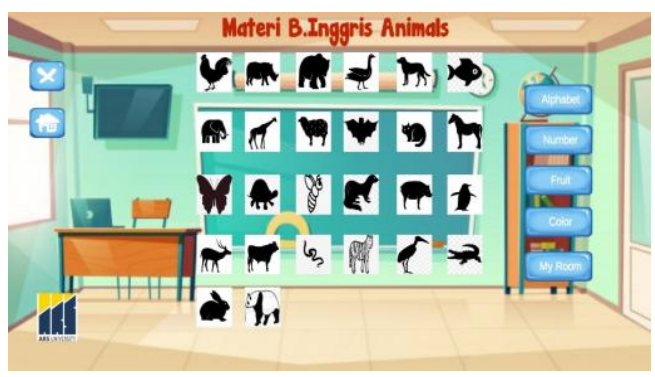

Gambar 13

Tampilan Materi Animals.

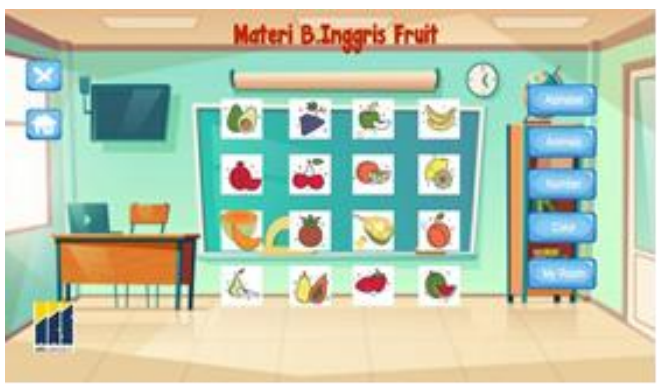

Gambar 14

Tampilan Materi Fruit.

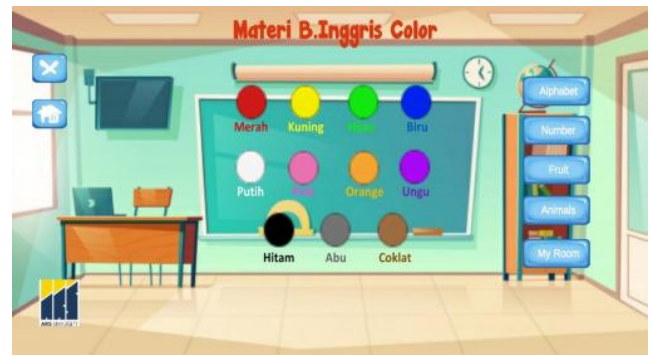

Gambar 15

Tampilan Materi Colors.

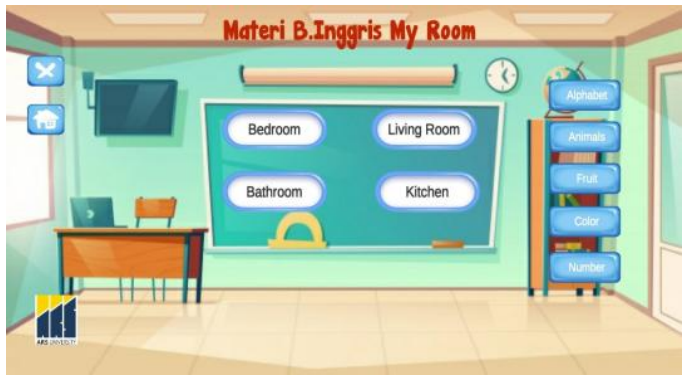

Gambar 16

Tampilan Materi My room.

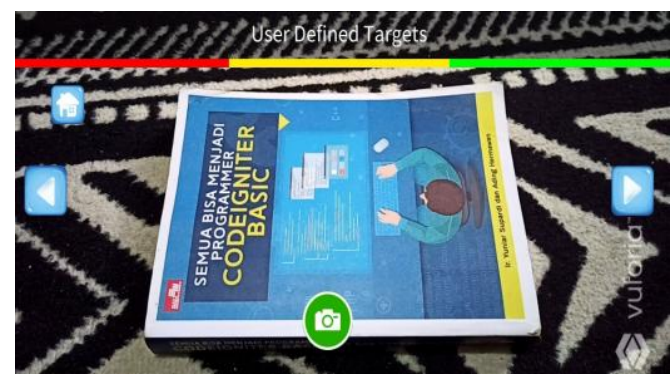

Gambar 17

Tampilan Deteksi Marker.

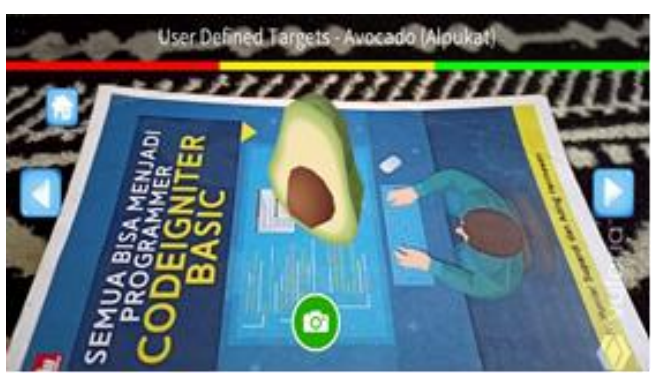

Gambar 18

Tampilan Objek 3D Muncul.

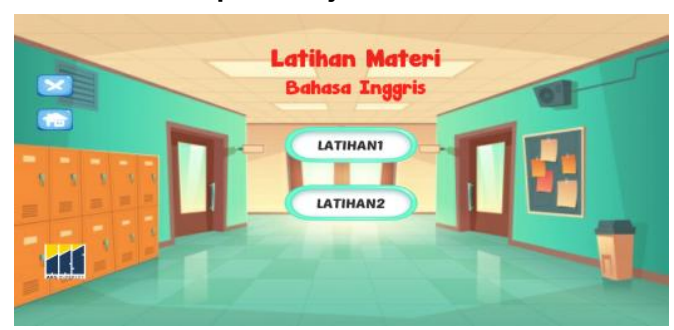

Gambar 19

Tampilan Menu Latihan.

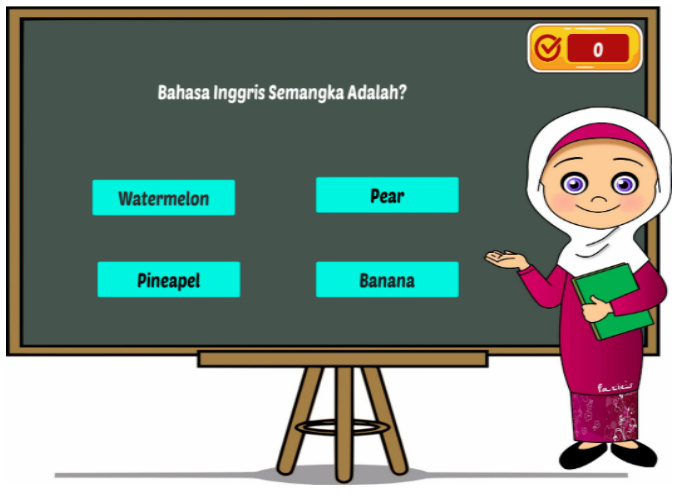

Gambar 20

Tampilan Latihan 1. 


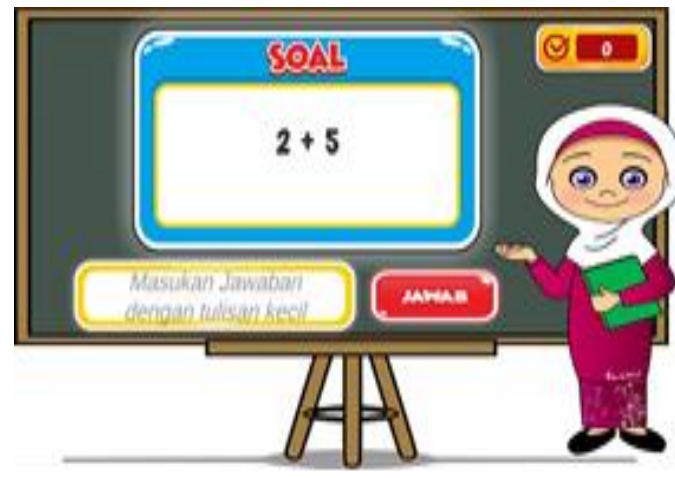

Gambar 21

Tampilan Latihan 2.

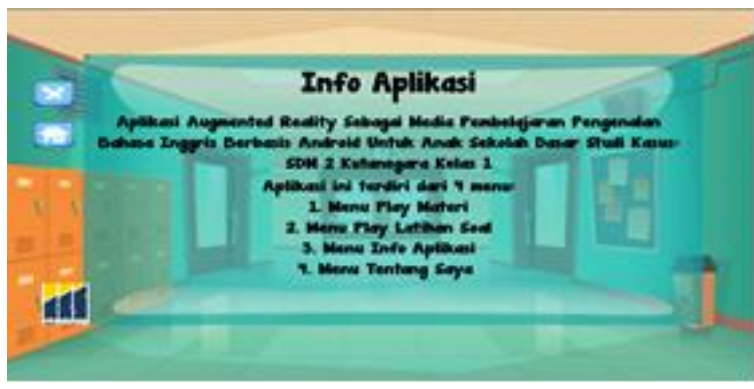

Gambar 22

Tampilan Menu Info Aplikasi.

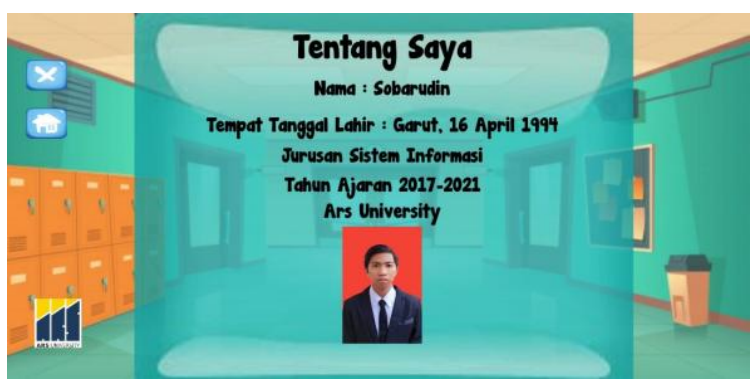

Gambar 23

Tampilan Menu Tentang Saya.

\section{KESIMPULAN}

Berdasarkan hasil penelitian maka dapat disimpulkan bahwa aplikasi augmented reality sebagai media pembelajaran pengenalan Bahasa Inggris untuk anak sekolah dasar studi kasus SDN 2 Kutanagara kelas 1 dilakukan dengan beberapa tahapan yaitu: melakukan analisis, lalu perancangan, setelah perancangan implementasi dan terakhir melakukan pengujian. Media pembelajaran augmented reality ini memiliki fitur AR kamera, menampilkan objek 3D huruf, number, buah, warna, binatang dan pengenalan ruangan menggunakan markerless, dapat membuat soal latihan tentang pengenalan Bahasa Inggris. Serta memunculkan suara pada saat objek 3D tampil.

\section{DAFTAR PUSTAKA}

[1] Husaini, M. (2014). Pemanfaatan Teknologi Informasi dalam Bidang Pendidikan (E-education). Jurnal Mikrotik, Vol. 2(1), 5p.

[2] Yusril, F.P. (2019). Pemanfaatan Teknologi Informasi Dalam Bidang Pendidikan (E-education). 2(1). https://doi.org/10.31219/osf.io/ycfa2

[3] Rachman. (2015). Pentingnya Pendidikan Sekolah Dasar. Disdik. https://disdik.bekasikab.go.id/beritapentingnya-pendidikan-sekolah-dasar.html [4] Kalena, N. satra. (2020). Pentingnya Belajar Bahasa Inggris Sejak Dini Siedoo. https://siedoo.com/berita-29916pentingnya-belajar-bahasa-inggris-sejakdini/ 
Infomatek Volume 23 Nomor 2 Desember 2021 : 107 - 114

[5] Mubaraq \& Kurniawan, A. S. (2018). Media Pembelajaran Buah-buahan Implementasi Augmented Reality Pada Berbasis Android. IT Journal, 6(1), 89-98. 